\title{
Corporeidade: o modo de ser incorporado na vida
}

\author{
VÂNIA LÚCIA KAMPFF *
}

* Doutoranda em Filosofia pela PUC-Rio

Bolsista CNPq
RESUMO O presente artigo visa uma primeira aproximação para aquilo que Martin Heidegger pensou sobre a questão do corpo. Nos acercaremos deste fenômeno através do escrito Os Seminários de Zollikon, que foram realizados a partir de1959 e se estenderam por mais de dez anos. Toda a questão parte de uma crítica à ciência moderna que determina incontestavelmente o modo como entendemos o corpo e se desdobra em uma compreensão original, pensada a partir de um modo de ser incorporado na vida, nomeado pelo pensador de corporeidade (Leiblichkeit).

PALAVRAS-CHAVE corpo; método; fenomenologia; transcendência; corporeidade.

"Por trás dos teus pensamentos e sentimentos, irmão, há um poderoso soberano, um sábio desconhecido - ele se chama Si-mesmo. Em teu corpo habita ele. Teu corpo é ele. Há mais razão em teu corpo do que em tua melhor sabedoria. E quem que sabe, por que teu corpo necessita justamente de tua melhor sabedoria?"

Nietzsche, Assim Falou Zaratustra, p. 33.

O Fı condutor deste artigo se dará principalmente através de um pensamento tardio de Heidegger, apresentado em Os Seminários de Zollikon. Como o título mesmo sugere, o escrito registra os encontros realizados na casa do médico Medard Boss, que começaram em 1959 e se estenderam por mais de dez anos, em Zollikon, na Suíça. Toda a questão do corpo parte de uma crítica à ciência moderna a qual, através de um método objetivante, - cujo princípio é o de que somente é real aquilo que pode ser 
calculado, mensurado e quantificado antecipadamente -, determina incontestavelmente o modo como entendemos o corpo.

Sabemos que o método ao qual o pensador se atém é denominado fenomenológico-hermenêutico. Trata-se de uma investigação filosófica que busca um retorno às coisas mesmas ao mesmo tempo que leva em consideração uma compreensão interpretativa. Pensar o corpo a partir de Heidegger deve nos encaminhar ao sentido formal de deixar ver por si mesmo aquilo que se mostra a partir de si mesmo. Mas, como é que o corpo se deixa ver a partir de si mesmo? Esta pergunta nos remete, de imediato, ao corpo humano, àquilo que vemos, tocamos, exploramos e que nos coloca como porta-vozes de um saber objetivado. Não! Não devemos nos apressar e concluir que o filósofo alemão, ao pensar o corpo, teria em mente o corpo biológico ou físico, pois, para o pensador, é justamente aquilo que não se mostra e, na maioria das vezes, se mantém velado que toma lugar privilegiado neste modo de se acercar das coisas. A fenomenologia do corpo pensada por Heidegger não se atém à descrição minuciosa dos diversos aspectos de um objeto já existente, sobre o qual podemos obter dados precisos. Todas as predeterminações são interditantes e pensar o corpo a partir do método fenomelógico-hermenêutico heideggeriano deve nos encaminhar para uma compreensão outra deste fenômeno. ${ }^{1}$

Para o filósofo alemão, o problema do corpo é um problema de método, na medida que este é o caminho pelo qual a natureza se põe apenas e unicamente como objeto de uma previsibilidade universal. Isto significa dizer que a verdade das coisas é constituída através de uma objetividade da natureza apreendida apenas de forma clara, segura e indubitável para o sujeito que a representa, e não como uma manifestação daquilo que vem à presença. Tendo em vista a certeza como critério da verdade, o método exaure e elimina tudo o que é duvidoso de modo a chegar a um fundamento absoluto e inabalável. Nos referimos aqui basicamente à ideia desenvolvida no escrito de René Descartes, Discurso

1 Torna-se, de antemão, importante a distinção oferecida pelo próprio Heidegger para o uso da palavra corpo: o pensador usa o vocábulo Leib para o corpo enquanto fenômeno e Körper para o corpo físico, biológico. Para o nosso estudo, esta é uma distinção fundamental, pois é exatamente o corpo enquanto fenômeno que nos interessa. 
sobre o Método, publicado em 1637, de que só é verdadeiro aquilo que é calculável no sentido de uma evidência matemática; fato que determinou o método da ciência moderna de asseguramento de previsibilidade da natureza, o qual busca saber aquilo com o que pode e deve contar em seus processos, e cujo objetivo principal é o de instaurar certezas sobre um número cada vez maior de coisas. Com isso, não só o homem assume o papel de sujeito que dá a medida da determinação possível da objetidade dos objetos, mas, a verdade passa a ser entendida como aquilo que pode ser demonstrado de modo evidente e incontestável para aquele que postula essa verdade. Heidegger entende que o problema do corpo é um problema de método na medida em que a ciência moderna, baseada no método cartesiano, acaba por reduzir a corporeidade do homem à objetividade do conhecimento da física ou da biologia. Para o pensador, é indispensável que passemos de uma compreensão meramente explicativa, sobre a qual temos algo em mente, para uma compreensão a partir do corpo que somos nós: um entendimento do corpo enquanto corporeidade, abertura. Para que possamos nos aproximar dessa outra visada que, no pensar do filósofo, nos remete ao mais originário, precisamos desviar o olhar do escopo do positivismo da ciência moderna e nos orientar por uma escuta e uma visão que se põem diante do fenômeno que emerge.

Sabemos, entretanto, que não há por parte do filósofo a intenção de estabelecer novos princípios para uma teoria do conhecimento, assim como Husserl pretendia. A fenomenologia para Heidegger não é um método que pressupõe uma técnica, mas, um modo de pensar a vida que envolve especialmente a nossa relação com o mundo à nossa volta. Se tomarmos a etimologia da palavra método, veremos que a própria palavra nos orienta para aquilo que originariamente o grego antigo pensou para esse termo: enquanto metá - tanto pode ser “dentro, em” ou “que segue, depois”; - hodós significa, “caminho, via, viagem.”2 O vocábulo método se circunscreve, portanto, à ideia de estarmos seguindo um caminho ou no caminho e não atrelados a uma técnica de pesquisa. O método é o caminho que conduz a um assunto, é a maneira de buscar algo. O que vai determinar o caminho é o próprio modo de ser do ente a ser estudado e não algo previamente estabelecido, traçado. Ao criticar o método científico, o filósofo alemão visa abrir o diálogo a uma outra compreensão acerca da questão do corpo. Trata-se de uma compreensão nada fácil. Então, logo perguntamos: como é compreender o corpo enquanto fenômeno?

2 BÖLTING, R. Dicionário Grego-Português. Rio de Janeiro: Instituto Nacional do Livro, 1953, pp. 378 e 415, respectivamente. 
O que é uma fenomenologia do corpo para Heidegger? Como podemos pensar o corpo nos distanciando de todas as determinações prévias que a ciência moderna nos ofertou ao longo do tempo?

Em primeiro lugar, lembremos que não se trata de pensarmos em uma fenomenologia sobre o corpo, mas, a partir do corpo que nós somos. Trata-se de consideramos a corporeidade a partir do "auto-desvelamento de uma experiência originária daquilo que somos como corpo"3; um modo de ser anterior à própria compreensão já constituída. O que Heidegger tem em mente parte da analítica existencial do Dasein como ser-no-mundo, algo que já estava presente desde Ser e Tempo e que pergunta pela constituição fundamental ontológica do Dasein e não por uma simples descrição de seus fenômenos ônticos. Isto não significa que Heidegger negue o caráter ôntico do corpo, afinal, a relação humana com o outro tem como premissa necessária o fisiológico. Mas, aquilo que aparece onticamente como corpo já surge à luz de uma abertura primordial, nomeada pelo pensador alemão como existência, mundo. Portanto, o horizonte da existencialidade do corpo não mais se refere ao âmbito da objetidade, mas, ao domínio do fenômeno, da dimensão da corporeidade (Leiblichkeit). Isto significa que, para o filósofo, o corpo assume um lugar ontológico, além do ôntico. Heidegger avança em seu raciocínio e diz que a corporeidade se determina a partir do modo de ser que é o meu. Vemos, com isso, que essa corporeidade não se determina por um fator externo, mas, é algo que diz respeito somente a mim e ao meu modo de ser. Mas, que modo de ser é esse? O pensador nos diz:

[...] o corporar é co-determinado pelo meu ser homem no sentido da permanência ekstática em meio aos entes da clareia (e) o limite do corporar [...] é o horizonte-do-ser no qual eu permaneço (aufhalten). Por isso, o limite do corporar se modifica constantemente pela mudança do alcance de minha estada. ${ }^{4}$

Esta parece uma daquelas sentenças enigmáticas. Busquemos, pois, alguma compreensão. Este pequeno trecho parece nos dizer que é o modo de abertura em que o homem se encontra que vai determinar a nossa compreensão de corporeidade. Além disso, o

3 HARADA, "Fenomenologia do Corpo: Situação como existência corporal. À guisa de uma fenomenologia da corporeidade”. In: Revista Cultura Vozes. Petrópolis: Vozes, n. 65, 1971, p.22.

4 HEIDEGGER, Seminários de Zollikon; ed. Medard Boss; trad. Grabriela Arnhold e Maria de Fátima de Almeida Prado. Petrópolis: Vozes; Bragança Paulista: Editora Universitária São Francisco, 2009a, p.123. 
pensador faz menção à permanência da abertura do corporar, a qual não é constante e se modifica de acordo com o alcance da estada, ou seja, trata-se de uma permanência que se dá quando e na medida em que nela nos encontramos engajados, integrados, fincados. Podemos, com isso, afirmar que o modo de ser ao qual o filósofo se refere não nos direciona para um fora, mas para um âmbito no qual nossa existência se encontra totalmente envolvida e tomada pela insistência no horizonte do ser. Mais adiante, Heidegger corrobora esta compreensão quando diz: “o corporar tem esta notável relação com o si-mesmo.”5 Com base no enunciado, podemos afirmar que o entendimento da corporeidade não só deve passar pela compreensão de ser si-mesmo, mas, de que há um nexo ontológico entre ambos, no qual o ser si-mesmo é condição fundamental para a dimensão da compreensão da corporeidade. Mas, como isso é possível se sabemos que nosso estar no mundo se dá, na maioria das vezes, de forma inautêntica e imprópria? Lembremos que, para Heidegger, é a angústia a tonalidade afetiva fundamental que, ao suspender todos os referenciais de mundo, abre a possibilidade de compreender o si-mesmo. Com ela, dá-se um ultrapassamento, não na forma de um ir além ou para fora de uma imanência, mas, uma ultrapassagem que nos direciona ao âmago daquilo que nós mesmo somos. Heidegger entende que, nessa ultrapassagem, o Dasein se torna pela primeira vez justamente ele mesmo. Para o pensador o nome do ser do ente é transcendência e é esta que constitui a ipseidade, aquilo que é o mais próprio do homem, sua constituição fundamental, a qual antecede qualquer comportamento. Em Ser e Tempo, o filósofo já afirmava que a questão da transcendência “[...] é privilegiada porque nela reside a possibilidade e a necessidade da individuação mais radical.” ${ }^{6}$ Por outras palavras: é somente através deste ultrapassamento, também chamado de transcendência, que o Dasein pode se relacionar com o seu mais próprio e, a partir disso, com os outros entes e com o mundo. Lembremos apenas que quando nos referimos ao termo relação, não estamos, de forma alguma, pensando na relação entre duas coisas ou entre um sujeito e um objeto. O que Heidegger tem em mente para a essência deste vocábulo se acerca da ideia de uma aproximação, um interesse, um corresponder a uma solicitação, uma resposta. Trata-se, efetivamente, de uma relação consigo mesmo, que transcende o mundo e abre o mundo como mundo.

5 HEIDEGGER, ibidem, p.124. Itálico do autor.

6 HEIDEGGER, Ser e Tempo; trad. Marcia Cavalcante Schuback. Petrópolis, RJ: Vozes; Bragança Paulista, SP: Editora Universitária São Francisco, 2012a., p.78. No sentido de criar uma unidade para as diferentes traduções, optamos por manter os termos presença e ser-aí no original alemão Dasein. 
Transcendência é, pois, em última instância, ser-no-mundo, sendo isto entendido não em sua facticidade, mas, a partir de um modo próprio de existir do Dasein. Isto significa que a compreensão de ser-no-mundo tem uma especificidade própria que não pode ser dada por nenhum conhecimento teórico. Caminhemos um pouco mais.

Sabemos que o Dasein como ser-no-mundo é sempre aquele que se encontra em meio a outros entes e só se determina efetivamente a partir de uma inter-relação incessante com esse mundo. Sabemos também que a noção de mundo para Heidegger não se prende ao lugar de manifestação do conjunto de entes. O mundo demarca o caráter ontológico de abertura do Dasein: um modo de ser em que o Dasein se abre ao seu mais próprio e percebe que sendo, se é. Assim, há que se pensar a relação deste com o todo que o cerca, ou seja, todo e qualquer modo de ser do Dasein deve ser levado em consideração. Neste sentido, não só o ser si-mesmo, que se refere ao caráter de transcendência enquanto um projetar-se compreensivamente em direção ao mundo é constitutivo do Dasein, mas, o ser-com (Mitsein) também assume um caráter originário na medida em que este sempre se ocupa de outros, razão pela qual não podermos dizer que há aí um solipsismo ou subjetivismo e, muito menos, que se trata de uma outra visada que se abre a partir de uma tomada de consciência, mas, da compreensão da própria relação com o mundo à nossa volta: de ser-com os outros e com as coisas que nos encontram e que são cocriadores de mundo na medida em que coparticipam da existência do Dasein como ser-no-mundo. Nada além do que ser-uns-com-os-outros-no-mundo, mas, nem tampouco, atrelado ao plano de um sujeito com o outro ou de um sujeito com um objeto, pois, “os ‘outros’ não significam todo o resto dos demais além de mim [...]. Os outros, ao contrário, são aqueles dos quais, na maior parte das vezes não se consegue propriamente diferenciar, são aqueles entre os quais também se está.”7 Portanto, não se trata de uma relação apartada, mas, sim, de uma correlação, de um entrelaçamento, de uma pertença, onde o ser-com deve ser entendido existencialmente na medida em que se trata de um mundo compartilhado (Mitwelt). Isto significa uma coexistência, uma relação de encontro com os outros onde não se estabelece nenhum referencial de diferença. Segundo Heidegger, o ser-com os outros pertence ao ser do Dasein e passa necessariamente pela compreensão do ser como sua constituição fundamental e sua manifestação possível. Mas, como podemos, então, entender o ser-com outros dos quais não se consegue propriamente diferenciar?

7 HEIDEGGER, Ser e Tempo; trad. Marcia Cavalcante Schuback. Petrópolis, RJ: Vozes; Bragança Paulista, SP: Editora Universitária São Francisco, 2012a, p.174. 
Para essa reflexão, nos atemos ao texto de Hermógenes Harada, intitulado "Fenomenologia do Corpo", no qual o autor nos oferece a bela imagem do velho pescador, de Hemingway. Trata-se de um exemplo no qual encontramos a expressão mais radical e originária da corporeidade explicitada a partir de uma experiência inserida na existência. Entendemos que esta experiência é capaz de atravessar o humano de tal forma que constitui o processo historial de toda uma vida. Referimo-nos a um atravessamento por um tal modo de ser que, ao se impor, revela uma estrutura totalizante de compreensão completamente integrada ao corpo. Segundo Harada, a figura do velho pescador revela um corpo engajado numa determinada situação. O vento, o mar, as tormentas, a vida e a morte, os êxitos e fracassos, todas essas situações formam os elos inevitáveis da facticidade que oprimem o velho pescador por todos os lados. Sua obstinação e persistência em cada adversidade o faz mergulhar mais fundo em seu destino. Quer suporte ou não, ele está rigorosamente ancorado na situação de pescador. Este processo que forja a sua história faz surgir seu corpo, um corpo velho e encarquilhado, que sempre experimenta o mar como situação, como horizonte, no corpo de sua vida. O que se segue nessa imposição do mar sobre o pescador, é que o pescador se torna a cada luta, sofrimento ou alegria mais pescador, ou seja, ele cresce junto com o mar em seu ser si-mesmo. Nele, tudo são marcas do mar. Como horizonte e dimensão, o mar e o pescador não estão apartados, i.e., o corpo do pescador e o mar não se põem objetivamente um para o outro, mas, sim, como abertura originária na medida em que nela se vive e se insere enquanto existência. O corpo do velho pescador, podemos dizer, incorporou o mar, integrou-se a ele, também se faz mar a cada vez, ao mesmo tempo em que o mar também se faz pescador. Nesta relação abre-se um mundo, um modo possível de ser vida. Trata-se de uma experiência que irrompe, ilumina e se faz vida encarnada, incorporada num fazer que é também história e destino de tudo o que se pode ser. A corporeidade assim compreendida não é outra coisa senão vida humana, na qual a ideia de corpo e alma são conceitos limitantes para aquilo que é a própria riqueza e exuberância da vida. Sabemos que esta não é uma compreensão fácil e que é sempre um desafio falar de corporeidade a partir de Heidegger. O fenômeno do corpo entendido a partir da existência é algo singular, nada perceptível ou materialmente apreensível, mas, absolutamente fundamental, pois fala da saga da vida humana elevando-se em júbilo e alegria como pura gratuidade. 


\section{REFERÊNCIAS BIBLIOGRÁFICAS}

BÖLTING, R. Dicionário Grego-Português. Rio de Janeiro: Instituto Nacional do Livro, 1953.

DESCARTES, R. Discurso sobre o Método. Petrópolis: Vozes, 2008.

FOGEL, G. Sentir, Ver, Dizer: Cismando Coisas de Arte e de Filosofia. Rio de Janeiro: Muad X, 2012.

HARADA, H. “Fenomenologia do Corpo: Situação como existência corporal. À guisa de uma fenomenologia da corporeidade”. In: Revista Cultura Vozes. Petrópolis: Vozes, n. $65,1971$.

HEIDEGGER, M. Introdução à Filosofia; trad. Marco Antonio Casanova. São Paulo: Martins Fontes, 2009b.

. Introdução à Metafísica; trad. Emmanuel Carneiro Leão. Rio de Janeiro: Tempo Brasileiro, 1999.

- Seminários de Zollikon; ed. Medard Boss; trad. Grabriela Arnhold e Maria de

Fátima de Almeida Prado. Petrópolis: Vozes; Bragança Paulista: Editora Universitária São Francisco, 2009a.

. Seminarios de Zollikon; trad. Ángel Xolocotozi Yáñez. México: Herder, 2013.

. Ser e Tempo; trad. Marcia Cavalcante Schuback. Petrópolis, RJ: Vozes; Bragança Paulista, SP: Editora Universitária São Francisco, 2012a.

__ "Sobre a Essência do Fundamento". In: Os Pensadores - Conferências e Escritos Filosóficos; trad. Ernildo Stein. São Paulo: Abril Cultural, 1996b.

Zollikon Seminars: Protocols - Converstion - Letters; ed. Medard Boss; trad. Franz Mayr and Richard Askay. Illinois: Northwestern University Press, 2001.

NIETZSCHE, F. Assim Falou Zaratustra; trad. Paulo César de Souza. São Paulo: Cia. das Letras, 2011. 